\title{
A Community-Engaged Weather and Soil Moisture Monitoring Network in the Roaring Fork Catchment of the Colorado River Headwaters
}

\author{
Elise Osenga ${ }^{1}$, Julie Vano ${ }^{1}$, and James Arnott ${ }^{1}$ \\ ${ }^{1}$ Aspen Global Change Institute
}

October 5, 2020

\begin{abstract}
Local community and research interest to better understand regional climate change impacts has led to the establishment of a long-term soil moisture and weather observation network in the Roaring Fork catchment of the Colorado River Headwaters. This catchment-wide suite of 10 stations collects frequent and continuous data on soil moisture, soil temperature, rain, air temperature, relative humidity, and (at some stations) snow across an elevational gradient from $1,800 \mathrm{~m}$ to $3,680 \mathrm{~m}$ in elevation. We demonstrate how this effort can support research on mountain hydrology with applications for resource management and climate change adaptation decision making. We also share perspectives on the value and opportunities a community science approach can bring to catchment studies moving forward. All data from this project are publicly available.
\end{abstract}

Title: A Community-Engaged Weather and Soil Moisture Monitoring Network in the Roaring Fork Catchment of the Colorado River Headwaters

Running Title: A Community-Engaged Weather and Soil Moisture Network

Authors:

Elise C. Osenga, Julie Vano, James C. Arnott

Author Institutional Affiliations:

Aspen Global Change Institute (all authors)

104 Midland Ave., Suite 205

Basalt, CO 81621

Acknowledgements:

This network was installed with local community support. We would like to extend special thanks to Pitkin County Open Space and Trails, City of Aspen, Aspen Community Foundation, Pitkin County Healthy Rivers and Streams, City of Glenwood Springs, Colorado Mountain College, and the Colorado Natural Heritage Program.

We would also like to thank the field technicians, interns, and volunteers who have assisted in the establishment and ongoing maintenance of this network: Asa DeHaan, Andrea Sanchez, Isabella Nevin, Hunter Brown, Hadley Heibert, Adam Korenblat, Michael Schuster, and Jeffrey Schnissel.

\section{Hosted file}


Catchment Special Issue_A Community-Engaged Weather and Soil Moisture Network.pdf available at https://authorea.com/users/364095/articles/484638-a-community-engaged-weather-andsoil-moisture-monitoring-network-in-the-roaring-fork-catchment-of-the-colorado-riverheadwaters

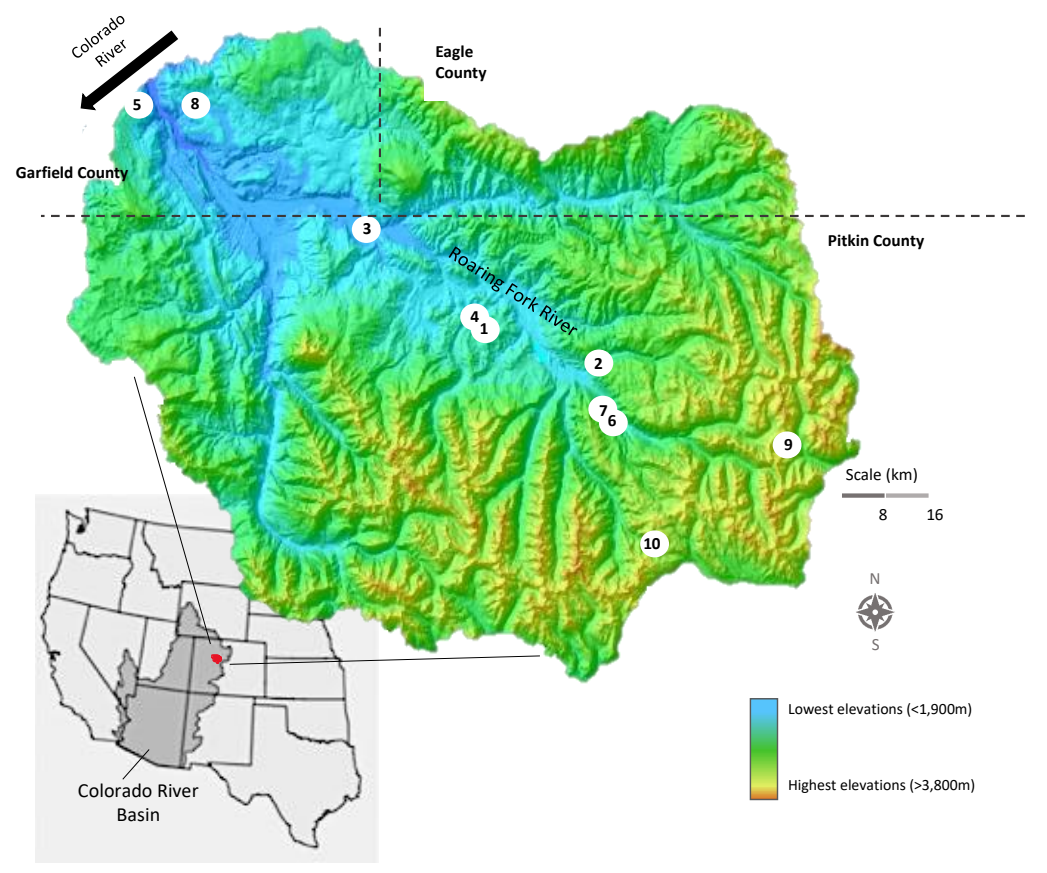

\section{Hosted file}

Table 1_A Community-Engaged Weather and Soil Moisture Network.pdf available at https:// authorea.com/users/364095/articles/484638-a-community-engaged-weather-and-soil-moisturemonitoring-network-in-the-roaring-fork-catchment-of-the-colorado-river-headwaters 